\title{
Livelihood Transitions and Changes of Sea Nomads or Urak Lawoi Fisher-folk in Response to Tourism on Lipe Island, Andaman Sea, Southern Thailand
}

\author{
Pilaiwan Prapruit ${ }^{1}$, Buncha Somboonsuke ${ }^{2}$, Ayut Nissapa ${ }^{2} \&$ Magnus Torell $^{3}$ \\ ${ }^{1}$ Tropical Agricultural Resource Management Programme, Faculty of Natural Resources, Prince of Songkla \\ University, Hat Yai, Songkhla, Thailand \\ ${ }^{2}$ Department of Agricultural Development, Faculty of Natural Resources, Prince of Songkla University, Hat Yai, \\ Songkhla, Thailand \\ ${ }^{3}$ Southeast Asian Fishery Development Center, Samutprakran, Thailand \\ Correspondence: Pilaiwan Prapruit, Tropical Agricultural Resource Management Programme, Faculty of Natural \\ Resources, Prince of Songkla University, Hat Yai, Songkhla 90112, Thailand. E-mail: ppilaiwa@yahoo.com
}

$\begin{array}{lc}\text { Received: April 16, } 2015 & \text { Accepted: May 26, } 2015 \quad \text { Online Published: July 29, } 2015 \\ \text { doi:10.5539/jsd.v8n6p174 } & \text { URL: http://dx.doi.org/10.5539/jsd.v8n6p174 }\end{array}$

\begin{abstract}
The Urak Lawoi fishing community on Lipe Island, Andaman Sea in Southern Thailand have faced challenges in the transition of livelihood patterns as well as from other changes due to rapid development of tourism sector on the island. This study aimed to investigate the transitions at the island and the changes to the Urak Lawoi community by employing a qualitative approach. Data collection was designed to analyze level and patterns of livelihood transitions and changes to the Urak Lawoi using field observation, interviews, and structured questionnaires. A total of 128 Urak Lawoi households were approached and engaged in formal interviews. Data obtained were analysed using descriptive statistics. Historical evidence revealed that the Urak Lawoi were the first inhabitants of the Lipe Island located just on the Thai side of the national border between Thailand and Malaysia. Looking back, there are four main periods affecting the lives and livelihood of the Urak Lawoi on the island; 1) first actual settlement of the Urak Lawoi on the island (at around 1897); 2) changes in social structure and decentralization that emerged in the period after the second World War; 3) intensive tourism on the island that followed major tourist promotions in the early 2000's; and 4) present stage with increased competition over resources and space. Tourism development affected in many ways on livelihood of the Urak Lawoi. Some impacts are more visible while other impacts are more difficult to distinguish. Among the obvious negative impacts there were an increase in sewage accumulation, poor relationship with park officials, and drug addiction among youths. Impacts defined as positive included improved convenience of travel to the mainland, increases in income and (material) benefits, and more occupation opportunities in tourism-related enterprises.
\end{abstract}

Keywords: livelihood, Urak Lawoi, fisher-folk, Lipe Island, traditional fisheries, local tourism, Andaman Sea

\section{Introduction}

Lipe Island is a small island in the Andaman Sea called Adang Archipelogo, $62 \mathrm{~km}$. off the south-western coast of Thailand (Wongbusarakum, 2007; Granbom, 2005). The island is located between Latitude $628-635$ North and Longitude 9909 - 9921 East and about $50 \mathrm{~km}$. north of the Malaysia's Langkawi Island as shown in Figure 1. Lipe Island has been the home of approximately 1,000 people of the Southeast Asian minority group, the Urak Lawoi. They are defined as sea nomads and mainly engaged in fishing in support of their traditional livelihoods (Paladej, 2009). The Urak Lawoi are well-known by the way their livelihoods are tightly connected with the coast and sea. The Urak Lawoi are sometimes referred to as "sea people" or "sea gypsy" because of the ways their life is related to the Sea. The Urak Lawoi minority group is one of the three ethnic groups in the Thai area of the Andaman Sea who have their own distinct language as well as their own culture (Hogan, 1972). Following processes of border demarcation between Thailand and UK/Malaysia in the end of the 1800's the Lipe Island was claimed to be with Thai territory. During the time of discussions on border demarcation the existence of the Urak Lawoi on the Lipe Island was recognized in 1897. 


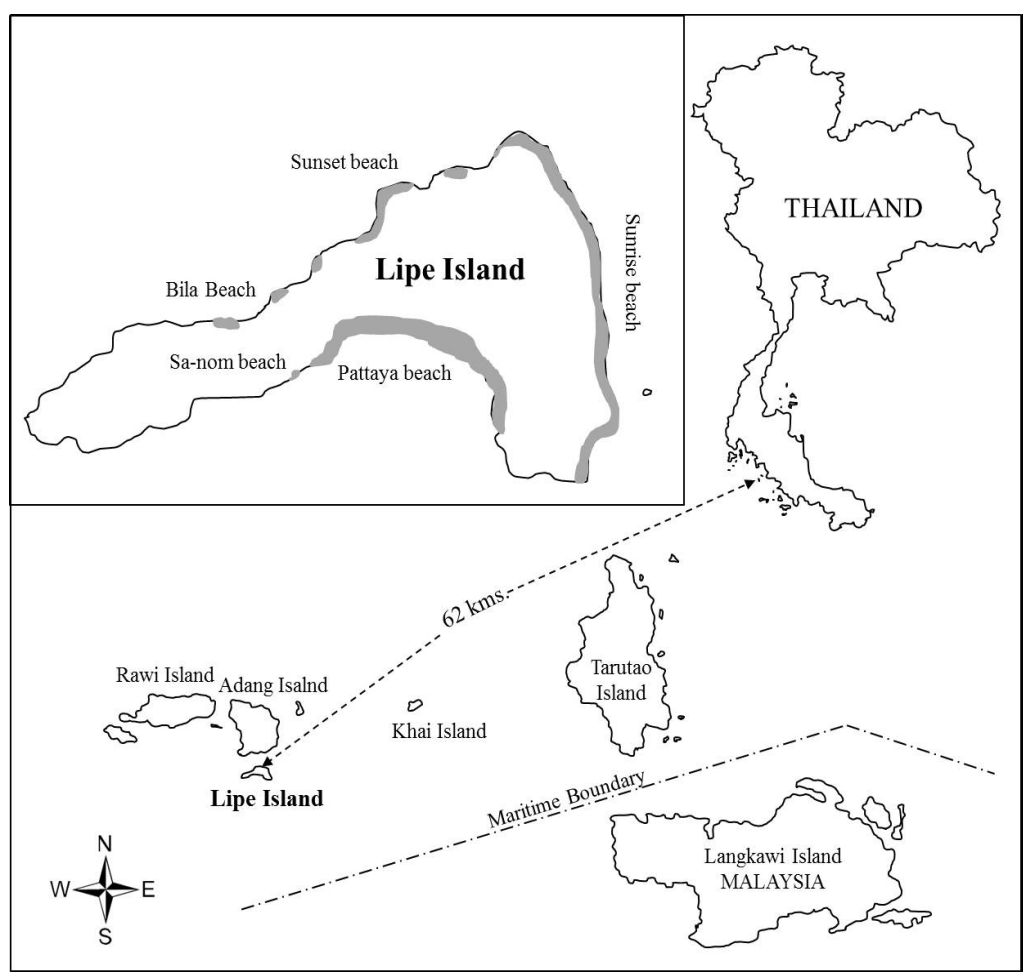

Figure 1. Map of Lipe Island

The inclusion of Lipe Island as a part of the Tarutao National Marine Park (19 April, 1974) has tremendously affected the livelihoods of the Urak Lawoi by requiring them to adjust the mobility of their livelihood patterns to become "aligned" with the national park's rules and regulations. In addition, the Unseen Thailand campaign of the Tourism Authority of Thailand in 2003 triggered an increase in number of tourists visiting the island generating income, employment opportunities and modernization. Hotels, resorts, home stays, restaurants and other tourism-related infrastructures were sprung up on the island adding significant livelihood changes to the Urak Lawoi's traditional fishing methods. Land disputes, freshwater scarcity and the uneven distribution of water, narcotic issues and cultural confusion have increasingly pressed on and the changes and completion over land and resources are difficult to deal with for the Urak Lawoi. Their traditional ownership of land and cultural inheritance together with their bargaining power as being the initial inhabitants of this island had substantially subsided.

Despite the tourism campaign, only 33 percent of Thai visitors to the Adang Archipelago were aware of the fishing practices and existence of the Urak Lawoi and nearly half of the visitors learned only after arriving that the Urak Lawoi have their own language and culture (Wongbusarakum, 2007). The unique landscape of the island with white sandy beaches, turquoise sea water, coral reefs, and the local culture have been the main attractions drawing foreign and Thai tourists alike to visit the island. Fisheries which were the traditional lifeline have become less prominent. The fishery of the Urak Lawoi is supporting tourists by providing food to the increasing number of restaurants in the increasing tourism industry.

Tourism is a fast growing industry contributing significantly to Lipe Island's economy. Tourism affects the economy and lives of local households and the fishing communities. The industry has proved to be a lifesaver for many communities and households along the Andaman Sea coast. There are real and perceived fears that sometimes, as with any other economic activities, island-tourism may have negative impacts on the local fishing communities. Tourism is a factor of change, but the direction of this change is uncertain (Monterrubio et al., 2011). Thus, the negative impacts should be minimised and measured against the benefits that tourism brings.

Objective of this study is to investigate the transition at the island and the changes to the Urak Lawoi community.

\section{Method}

To understand the patterns of transition and change to the livelihood of the Urak Lawoi including their responses 
over time, a timeline method was used. Primary qualitative data were obtained through focus group discussions and in-depth interviews. Thirty-five key informants participated in two focus group discussions. They were elders, village leaders, Urak Lawoi fishers, and representatives from a women group. Twelve key informants joined in the in-depth interviews. A questionnaire was developed as a tool to investigate impacts of tourism on the livelihood Urak Lawoi.

According to the population census of Civil Registration Database, there were 237 households registered as residents on Lipe Island in 2013. Among these households there were 138 fishing households. In preparation for this study the research team were able to engage a total of 128 fishing households to provide information for the studies ( $92.75 \%$ of the total number of fishing households). Forty-seven indicators were used and clustered under nine livelihood sub-indices, namely household status, occupation, social relationship, daily life, clothing, consumption behaviour, language, sanitation and health, and culture-traditional-belief.

The assessment of the impact on the community with reference to the 47 indicators was determined by using a rating scale method (1- the least impact, 5- the most impact). The scores indicated by the surveyed households were then averaged. Livelihood indices of "1.00-1.66", "1.67-3.35" and "3.36-5.00" were interpreted as "Low", "Medium" and "High", respectively.

\section{Results}

3.1 Social, Developmental and Environmental Perspectives on the Prospects for the Future Livelihood of the Urak Lawoi on Lipe Island

The livelihood pattern of the Urak Lawoi on Lipe Island is unique. By examining their houses; daily life, diseases and health care facilities together with local beliefs and traditional practices the research team could summarize the Urak Lawoi basic livelihood situation as follows;

- Houses and accommodation: There are a wide variety of houses including traditional huts, wooden huts with tin or concrete roof, bungalows with semi concrete and wooden houses, concrete bungalows, two stories houses and government designed houses for teachers.

- Daily life, rights and tenure rights: The Urak Lawoi at Lipe Island presently face problems of congestion as they are forced to cluster their houses to pave way for tourism expansions which also limits their rights to have proper living conditions with recreational space. The problems are connected to uncertain land ownerships allowing outsiders to enter the island and claim/buy land, Following the expansion of tourist resorts the Urak Lawoi are also suffered from limited access to beaches, waterfront and seabed. Other identified problems that impedes on the quality of life include high prices for an access to electricity, shortage of fresh water, floods, garbage accumulation and insufficient solid waste management and unhygienic standard of living.

- Diseases and health care. The most common diseases on the island are diseases related to indigestion such as diarrhea. Other frequent problems include skin diseases and fever. There has been no record of sexually transmitted diseases and AIDS, but there were rumours about it.

- Local beliefs and tradition. Most of the Urak Lawoi community members are believers of their ancient tradition and values. Their animistic beliefs are inherited through generations and their traditional festivities based on use of ceremonial boats are still maintained. Unfortunately, some of the traditional ceremonies are being less observed by the community members, this includes the Tulabala (eradication of bad faiths), the Yapunyu (worship of sea turtles), and the Yalawoi (worship of the sea and ocean) ceremonies. If being observed these ceremonies can provide effective means to maintain the respect for marine life, and strengthen the awareness of the importance of the conservation of the sea and the ocean.

\subsection{Transitions in the Livelihood of the Urak Lawoi on Lipe Island}

Livelihoods of the Urak Lawoi fisher-folk have gone through several transitions and changes in three distinct periods namely, (1) first settlement on Lipe Island around and before 1897, (2) changes in social structure and Thai decentralization (1994-2007), and (3) intensive tourism development on Lipe Island (2008-2014). The impacts on the Urak Lawoi livelihoods during each of these periods can be analysed focusing on visible and important aspects of community well-beings, such as community cohesion, livelihoods, daily life, health and sanitation, and beliefs-traditions and ceremonies. The result from the analysis is shown in Table 1. 
Table 1. Visible and important factors of change affecting the Urak Lawoi

\begin{tabular}{|c|c|c|c|}
\hline $\begin{array}{c}\text { Period and } \\
\text { Aspects }\end{array}$ & $\begin{array}{l}\text { First settlement on Lipe Island } \\
\text { (around or before 1897) }\end{array}$ & $\begin{array}{c}\text { Changes in social structure and Thai } \\
\text { decentralization (1994-2007) }\end{array}$ & $\begin{array}{l}\text { Intensive tourism development on Lipe } \\
\text { Island (2008-2014) }\end{array}$ \\
\hline $\begin{array}{l}\text { Community } \\
\text { cohesion }\end{array}$ & $\begin{array}{l}\text { There were small scale fishing } \\
\text { communities scattered along beaches } \\
\text { and bays. The Urak Lawoi } \\
\text { fisher-folk built simple half lifted } \\
\text { wooden houses using materials } \\
\text { found on the island. }\end{array}$ & $\begin{array}{l}\text { The population at Lipe expanded in response } \\
\text { to increasing population from natural growth } \\
\text { and immigration of mainland Thais. There } \\
\text { were presences of Tao Kae or trade } \\
\text { middlemen and government officials } \\
\text { working with the Urak Lawoi. }\end{array}$ & $\begin{array}{l}\text { The Lipe population further expanded } \\
\text { comprising of 1) traditional Urak Lawoi; 2) } \\
\text { mainland Thais working on the island, 3) } \\
\text { foreigners forming business partnerships } \\
\text { with the Urak Lawoi or being assistants to } \\
\text { work for free lodging and food or marriage } \\
\text { with the Urak Lawoi, and 4) foreign labour } \\
\text { especially from Myanmar to work in } \\
\text { resorts and hotels. }\end{array}$ \\
\hline Livelihoods & $\begin{array}{l}\text { The Urak Lawoi family engaged in } \\
\text { subsistent fisheries using simple } \\
\text { fishing gears. Their indigenous } \\
\text { fishing techniques were important } \\
\text { for their livelihoods. Main fishing } \\
\text { gears were throwing spear, and line } \\
\text { and hook. Apart from fishing } \\
\text { activities, they grew rice and coconut } \\
\text { primarily for household } \\
\text { consumption. }\end{array}$ & $\begin{array}{l}\text { Capture fisheries remained to be an } \\
\text { important source of the Urak Lawoi's } \\
\text { livelihoods. Indigenous fishing techniques } \\
\text { were still in use for some Urak Lawoi } \\
\text { households, while commercial fisheries } \\
\text { emerged alongside with it. Tao Kae system } \\
\text { entered into the island which promoted the } \\
\text { use of modern fishing gears. The Urak Lawoi } \\
\text { started using large sitting cage, dynamite and } \\
\text { net as their fishing methods. }\end{array}$ & $\begin{array}{l}\text { Capture fisheries continued to be the } \\
\text { lifeline of the Urak Lawoi, but more as } \\
\text { their permanent custom. They spent more } \\
\text { time on other activities related with tourism } \\
\text { either as; (1) their own business, (2) } \\
\text { employees in others' business, or (3) leased } \\
\text { out their premises for resorts and hotels, } \\
\text { and tourists' related business. They gained } \\
\text { higher income from these deals than from } \\
\text { fisheries. }\end{array}$ \\
\hline Daily life & $\begin{array}{l}\text { The Urak Lawoi occupied } \\
\text { themselves with fisheries all year } \\
\text { roundng. During summer, they } \\
\text { worked on "Bakat" fisheries for as } \\
\text { long as 2-3 days or many months. } \\
\text { Their daily life was to seek food } \\
\text { from the sea, needed materials from } \\
\text { natural surroundings. Simple seafood } \\
\text { processing was used such as salt } \\
\text { based pickled and grill. Their basic } \\
\text { handicrafts were floor mat and } \\
\text { various shapes of baskets. }\end{array}$ & $\begin{array}{l}\text { Simple daily life still existed based on } \\
\text { assigned roles and duties. The Urak Lawoi } \\
\text { men set out for fishing while women did } \\
\text { household chores. Children age between } 8-15 \\
\text { years attended school. Many Urak Lawoi } \\
\text { households were employed by Tao Kae, } \\
\text { some took loans from Tao Kae to buy } \\
\text { motorized fishing boats. When market } \\
\text { system entered into the island, The Urak } \\
\text { Lawoi men started to addict to alcohol, and } \\
\text { card gambling games became popular among } \\
\text { both men and women. }\end{array}$ & $\begin{array}{l}\text { The Urak Lawoi women worked at least } \\
\text { two shifts as housewives and resort maids, } \\
\text { while men worked as tourist boat operators } \\
\text { during tourist season. The Urak Lawoi men } \\
\text { turned to capture fisheries after the end of } \\
\text { the tourist season. Alcohol drinking was } \\
\text { still popular activity after work among } \\
\text { men, while women played cards and bet on } \\
\text { lottery. The Urak Lawoi children played } \\
\text { sports or traditional game. For elders, they } \\
\text { helped in taking care of children or } \\
\text { employed in odd jobs such as grass cutting } \\
\text { or vegetable sale. }\end{array}$ \\
\hline $\begin{array}{l}\text { Health and } \\
\text { sanitation }\end{array}$ & $\begin{array}{l}\text { Fresh water was collected from } \\
\text { underground wells, waterfalls or } \\
\text { creeks for household consumption. } \\
\text { Open-air toilet on the beaches was a } \\
\text { normal practice. When they got sick, } \\
\text { the Urak Lawoi utilized naturally } \\
\text { found herbs and sea creatures as } \\
\text { healers. Magic or magic with herbs } \\
\text { were their choices of medication. }\end{array}$ & $\begin{array}{l}\text { Although a Public Health Office was } \\
\text { established on the island, the Urak Lawoi } \\
\text { were still attached to their ancient healers. } \\
\text { Modern medicine started to become a } \\
\text { parallel medication. But their toilet was still } \\
\text { open air on submerged beaches and forest. } \\
\text { Their house and yard were kept tidy and } \\
\text { clean. Fresh water was draw from } \\
\text { underground wells for household uses, but } \\
\text { for consumption they used water from creeks } \\
\text { or waterfalls on Adang and Rawi Islands. }\end{array}$ & $\begin{array}{l}\text { Public water and underground water were } \\
\text { used for washing. Proper toilets were built } \\
\text { inside or outside the houses. The local } \\
\text { administrative organization provided } \\
\text { garbage bins around the community. The } \\
\text { Urak Lawoi utilized more services from } \\
\text { Public Health Office, except for child } \\
\text { delivery. They still preferred The Urak } \\
\text { Lawoi midwife (Moh Tum Yae - Ms. } \\
\text { Ropiah Harnthalae and Ms. Suisin } \\
\text { Harnthalae) }\end{array}$ \\
\hline
\end{tabular}




\begin{tabular}{|c|c|c|c|}
\hline $\begin{array}{l}\text { Period and } \\
\text { Aspects }\end{array}$ & $\begin{array}{l}\text { First settlement on Lipe Island } \\
\text { (around or before 1897) }\end{array}$ & $\begin{array}{c}\text { Changes in social structure and Thai } \\
\text { decentralization (1994-2007) }\end{array}$ & $\begin{array}{l}\text { Intensive tourism development on Lipe } \\
\text { Island (2008-2014) }\end{array}$ \\
\hline $\begin{array}{l}\text { Beliefs, } \\
\text { traditions } \\
\text { and } \\
\text { ceremonies }\end{array}$ & $\begin{array}{l}\text { The Urak Lawoi did not have a } \\
\text { formal religion. They believed in } \\
\text { animism, worshipped ghosts and } \\
\text { ancestor spirits. Their traditions } \\
\text { were: } \\
\text { - Ceremonial boat tradition. It was } \\
\text { a bi-annual ceremony on the full } \\
\text { moon nights of the sixth and } \\
\text { eleventh months. } \\
\text { - Yapinyu tradition. It was the } \\
\text { tradition to worship sea turtle on } \\
\text { the full moon nights of the fifth } \\
\text { and eleventh months. The purpose } \\
\text { of this ceremony was to } \\
\text { encourage sea turtles to lay their } \\
\text { eggs. } \\
\text { - Puya Lawoi tradition. Aimed at } \\
\text { worshiping the sea on the full } \\
\text { moon night of the eleventh } \\
\text { month. It encouraged all aquatic } \\
\text { animals to lay eggs along the } \\
\text { island coast so that the Urak } \\
\text { Lawoi fishers were guaranteed } \\
\text { abundant seafood and good catch. } \\
\text { - Tulabala tradition. This tradition } \\
\text { was aimed at eradicating bad } \\
\text { spells at times when diseases } \\
\text { were wide spread. } \\
\text { In addition to these traditions, there } \\
\text { were other supernatural beliefs such as } \\
\text { love portion, sacred spells for healing, } \\
\text { good luck timing and other spells for } \\
\text { many purposes such as boat worship, } \\
\text { presence in the kitchen while } \\
\text { cooking, no play on the beach during } \\
\text { some certain night (11-12 waxing } \\
\text { moon). }\end{array}$ & $\begin{array}{l}\text { The Urak Lawoi continued the beliefs in } \\
\text { ghosts and ancestor spirits. The traditions and } \\
\text { ceremonies that had been practiced through } \\
\text { generations continued. The Thai government } \\
\text { attempted to introduce Buddhism to the Urak } \\
\text { Lawoi on Lipe Island by promoting Buddhist } \\
\text { practices and chants in schools and at public } \\
\text { work during Buddhist holidays. The late } \\
\text { Queen mother visited the Lipe Island on } \\
\text { February 13, 1967. She brought with her a } \\
\text { Buddha image and Buddhist books to be kept } \\
\text { in the school. Therefore Buddhism was } \\
\text { commenced and established on the island. } \\
\text { Some Urak Lawoi traditions such as Yapinyu } \\
\text { tradition was given up or became less } \\
\text { prominent, while the Puya Lawoi tradition } \\
\text { was annexed with the ceremonial fishing } \\
\text { boat tradition. }\end{array}$ & $\begin{array}{l}\text { There were alterations in the ceremonial } \\
\text { boat tradition from using oarsmen boats to } \\
\text { motorized boats. The main purpose of the } \\
\text { tradition was to worship the Urak Lawoi } \\
\text { ancestors and obtain blessings for } \\
\text { successful fisheries. During this period } \\
\text { when tourism industry was heavily } \\
\text { promoted, some obstruction to the tradition } \\
\text { frequently occurred due to late arrival of } \\
\text { some important persons from outside the } \\
\text { community. }\end{array}$ \\
\hline
\end{tabular}

The Urak Lawoi community life and livelihoods are closely knitted with the sea and its resources. They possess capability and expertise in fishing, including the indigenous knowledge on marine and coastal ecosystem, and how to manage them. This unique knowledge is considered to be a human capital asset specific to the area. Information from interviews with the Urak Lawoi was mostly qualitative in nature, the scoping matrix was utilized to arrange data for the revelation of relationships among fishing gears and various issues reflecting the sub-ecosystems. The main sub-ecosystems included in the scoping, mainly are; (1) shallow water area around the island's coast, (2) areas around rock formations in the sea, (3) water surface around the island, (4) deep water far from the island's coast, and (5) deep sea area with depth about 5-7 meters from sea surface. The relationships between preferred gear and sub-ecosystem are summarized in Table2.

Table 2. Fishing sub-ecosystem around the Lipe Island

\begin{tabular}{|c|c|c|c|c|}
\hline Fishing gears & Harvesting methods & Sub-ecosystems for fishing & $\begin{array}{l}\text { Harvesting } \\
\text { period }\end{array}$ & Species captured \\
\hline $\begin{array}{l}\text { Small fishing } \\
\text { trap }\end{array}$ & $\begin{array}{l}\text { Using boat to place the } \\
\text { cages/traps }\end{array}$ & $\begin{array}{l}\text { Shallow water area around the } \\
\text { island coast }\end{array}$ & 5-7 days & $\begin{array}{l}\text { Rainbow runner, Longfin cavalla, Snake } \\
\text { skin gourami }\end{array}$ \\
\hline $\begin{array}{l}\text { Large fishing } \\
\text { trap }\end{array}$ & $\begin{array}{l}\text { Using boat to place the } \\
\text { cages/traps }\end{array}$ & $\begin{array}{l}\text { Around rock formation area in } \\
\text { the sea }\end{array}$ & 2 weeks & $\begin{array}{l}\text { Orange spotted grouper, Tiger grouper, } \\
\text { Rainbow runner, Spadefish, Parrotfish, } \\
\text { True eel }\end{array}$ \\
\hline $\begin{array}{l}\text { Indo hook and } \\
\text { line }\end{array}$ & Long line hooks & $\begin{array}{l}\text { Water surface around the } \\
\text { island }\end{array}$ & Daytime & $\begin{array}{l}\text { Hard-tail scad, Indo-pacific Spanish } \\
\text { mackerel, Striped large-eye bream, and } \\
\text { Indian mackerel }\end{array}$ \\
\hline $\begin{array}{l}\text { Simple } \\
\text { fishing hook }\end{array}$ & $\begin{array}{l}\text { Fishing boat using hook and } \\
\text { lure }\end{array}$ & $\begin{array}{l}\text { Deep water far from island } \\
\text { coast }\end{array}$ & Daytime & Spanish mackerel, Leopard grouper \\
\hline
\end{tabular}




\begin{tabular}{|c|c|c|c|c|}
\hline Fishing gears & Harvesting methods & Sub-ecosystems for fishing & $\begin{array}{l}\text { Harvesting } \\
\text { period }\end{array}$ & Species captured \\
\hline Spear gun & $\begin{array}{l}\text { Diving to spear or spearing on } \\
\text { the boat }\end{array}$ & $\begin{array}{l}\text { Deep sea area with depth } \\
\text { about } 5-7 \text { meters from sea } \\
\text { surface }\end{array}$ & $\begin{array}{l}\text { At time of clear } \\
\text { water }\end{array}$ & $\begin{array}{l}\text { Sea cucumber, Green shrimp (coral } \\
\text { shrimp), King Kong shrimp, Gamat, } \\
\text { Holothuria scabra, Black sea cucumber }\end{array}$ \\
\hline Purse seine & $\begin{array}{l}\text { Releasing purse seine while } \\
\text { operating boat, harvesting } \\
\text { after complete the round }\end{array}$ & 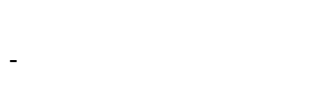 & $\begin{array}{l}\text { During } \\
\text { dark-moon night }\end{array}$ & $\begin{array}{l}\text { Spanish mackerel, Longtail tuna, Hardtail } \\
\text { scad }\end{array}$ \\
\hline Long spear & \multirow{2}{*}{\multicolumn{4}{|c|}{$\begin{array}{l}\text { Popular in the past. It is difficult to use because of its long handle, good for spearing fish hiding inside reef cliffs. } \\
\text { In the past, dynamite fishing was used to exchange necessary items from middlemen or financial returns. They used fertilizers and } \\
\text { some chemicals for mixtures, catch amount was about } 1,000-10,000 \mathrm{~kg} \text {. }\end{array}$}} \\
\hline $\begin{array}{l}\text { Dynamite } \\
\text { fishing }\end{array}$ & & & & \\
\hline
\end{tabular}

It can be seen that there are at least 5 identified sub-ecosystems. To make the relationships clearer, fishing gears are classified based on their uses in two areas, shallow water area around the island and deep water area farther away from the coast as shown in Figure 2. The spear gun and Indo hook and line can be found in both areas.

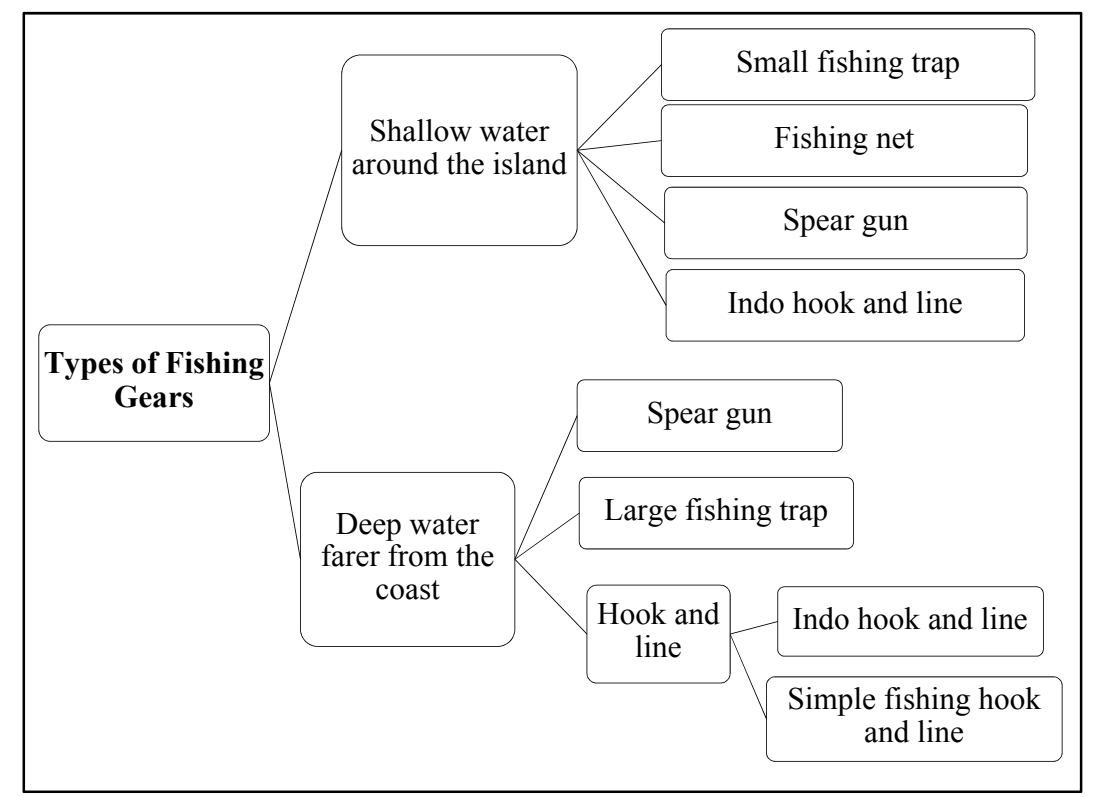

Figure 2. Fishing in two groups of sub-ecosystems

\subsection{Patterns of Livelihood Transitions and Occupational Changes}

Tourism development on Lipe Island has begun with the establishment of the Tarutao Marine National Park since 1974. The park embraced and promoted tourism in marine protected areas. The important criteria for tourists to select Lipe Island as their destination are the unspoilt natural environment, convenience/safety, peacefulness, low level of commercial tourism, low development level, value for money, and local culture and people, respectively (Wongbusarakum, 2002). The relationships between fishing communities and tourists have been mutually benefited and welcomed by both parties. The growth of the tourism industry has not only affected the fishing communities in a positive manner but has also had negative impacts on their livelihoods.

The traditional fishery on the island before the arrival of the early tourists was entirely made up of capture fisheries for household consumption and trading. The coming of tourism and its related business was rapidly followed by changes in the traditional pattern. The fishers are now engaging in more diverse occupations closely related with the growth of tourism industry such as tourist and commuting boat operators, diving tour guides, restaurant owners and employees, resort owners and employees, local government officers, wage laborers, and self-employed entrepreneurs as shown in Figure 3. 


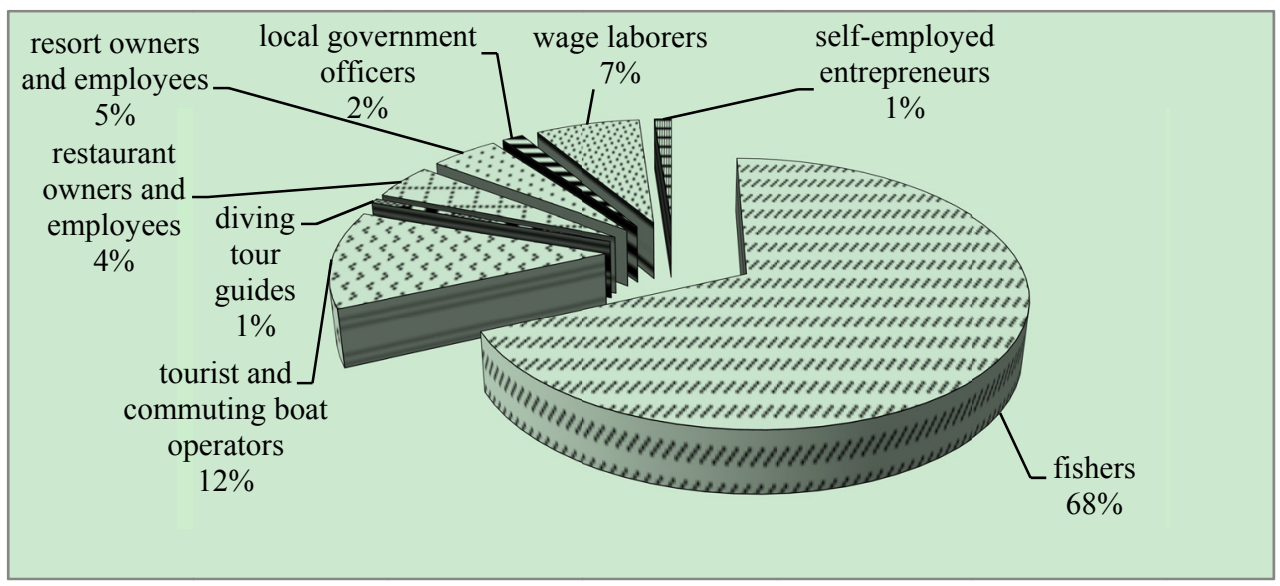

Figure 3. Proportional change and diversity of fishers' occupation

Fishers started to engage in more than one occupation especially during tourism high season (November - May). They still regard capture fisheries as their most vital occupation as it provides them with immediate source of income and food for daily household consumption. Even though some households stated that capture fisheries has turned out to be their supplementary occupation, most are still giving higher priority to fisheries as their source for survival and important tradition. They give more value to self-sought food from the sea than food bought from markets. With regard to capture fisheries, there are two types of fishing operations, (i) independent fishers and (ii) those employed by the local Tao Kae system. The fishers who stated that capture fisheries was their main occupation preferred to adopt the Tao Kae system as they did not need to invest in important costs such as petrol, and there was a minimal price risk. The independent fishers stated that they engage in dual occupations, i.e., capture fisheries alongside with tourist boat operation, and other tourism-related businesses.

The households' monthly income in the months before the tourism season were as stated by the Urak Lawoi between 152.54 USD to 305.07 USD and capture fisheries was the main source of this income. But during the tourism high season their monthly income ranged between 152.54-915.22 USD and the main source of income were from tourism related activities and capture fisheries.

The extent and impact on the livelihood of Urak Lawoi households following the transitions and changes due to tourism can be shown in an impact index. The results were identified by a scaling of the perceptions (positive and/or negative) on transition and change facing the Urak Lawoi due to the tourism development as shown in Table 3.

Table 3. Perception of the Urak Lawoi on livelihood transition and changes due to tourism development $n=128$

\begin{tabular}{|c|c|c|c|c|}
\hline \multirow[t]{2}{*}{ Items } & \multicolumn{2}{|c|}{$\begin{array}{c}\text { Positive } \\
\text { transitions/changes }\end{array}$} & \multicolumn{2}{|c|}{$\begin{array}{c}\text { Negative } \\
\text { transitions/changes }\end{array}$} \\
\hline & Score & $\begin{array}{l}\text { Level of } \\
\text { transition }\end{array}$ & Score & $\begin{array}{l}\text { Level of } \\
\text { transition }\end{array}$ \\
\hline \multicolumn{5}{|l|}{ 1. Household conditions } \\
\hline Recreation areas around houses & - & - & 3.30 & Medium \\
\hline Changing housing materials (wood, concrete) & 3.10 & Medium & - & - \\
\hline Drug addiction among youths & - & - & 3.86 & High \\
\hline Convenience commuting with mainland & 3.57 & High & - & - \\
\hline Convenience commuting on the island & 3.46 & High & - & - \\
\hline Convenient access to electricity & 3.44 & High & - & - \\
\hline \multicolumn{5}{|l|}{ 2. Occupation } \\
\hline Opportunities for alternative tourist-related occupation & 3.50 & High & - & - \\
\hline Income increments & 3.54 & High & - & - \\
\hline Fish harvest & - & - & 3.47 & High \\
\hline Access to land on the island & - & - & 3.43 & High \\
\hline Access to sea grounds & - & - & 3.36 & High \\
\hline \multicolumn{5}{|l|}{ 3. Social relationship } \\
\hline Relationship between fishing households and relatives & - & - & 3.32 & Medium \\
\hline Relationship between fishing households and in community & - & - & 3.31 & Medium \\
\hline $\begin{array}{l}\text { Relationship between fishing households and formal community } \\
\text { leaders }\end{array}$ & - & - & 3.59 & High \\
\hline Relationship between fishing households and cultural leaders & - & - & 3.19 & Medium \\
\hline Relationship between fishing households and health officers & 2.88 & Medium & - & - \\
\hline
\end{tabular}




\begin{tabular}{|c|c|c|c|c|}
\hline \multirow[t]{2}{*}{ Items } & \multicolumn{2}{|c|}{$\begin{array}{c}\text { Positive } \\
\text { transitions/changes }\end{array}$} & \multicolumn{2}{|c|}{$\begin{array}{c}\text { Negative } \\
\text { transitions/changes }\end{array}$} \\
\hline & Score & $\begin{array}{l}\text { Level of } \\
\text { transition }\end{array}$ & Score & $\begin{array}{l}\text { Level of } \\
\text { transition }\end{array}$ \\
\hline $\begin{array}{l}\text { Relationship between fishing households and teachers on the } \\
\text { island }\end{array}$ & 2.67 & Medium & - & - \\
\hline Relationship between fishing households and police/navy officers & - & - & 3.36 & Medium \\
\hline Relationship between fishing households and local administrators & - & - & 3.34 & Medium \\
\hline Relationship between fishing households and fishery officers & - & - & 2.93 & Medium \\
\hline $\begin{array}{l}\text { Relationship between fishing households and national park } \\
\text { officers }\end{array}$ & - & - & 3.92 & High \\
\hline Relationship between fishing households and foreigners & 3.43 & High & - & - \\
\hline $\begin{array}{l}\text { Relationship between fishing households and Thai business } \\
\text { people from mainland }\end{array}$ & 2.95 & Medium & - & - \\
\hline Trust among fishing households members & - & - & 3.11 & Medium \\
\hline Community co-operations & - & - & 3.42 & High \\
\hline \multicolumn{5}{|l|}{ 4. Daily life } \\
\hline Lottery gambling/stock market & - & - & 3.43 & High \\
\hline Self-confident & 2.72 & Medium & - & - \\
\hline \multicolumn{5}{|l|}{ 5. Clothing } \\
\hline Clothing of female teenager & 3.10 & Medium & - & - \\
\hline Clothing of male teenager & 3.09 & Medium & - & - \\
\hline Clothing of mature female & 3.25 & Medium & - & - \\
\hline Clothing of mature male & 3.23 & Medium & - & - \\
\hline Clothing of mature elders & 3.22 & Medium & - & - \\
\hline \multicolumn{5}{|l|}{ 6. Food consumption behaviors } \\
\hline Number of meals per day & 2.93 & Medium & - & - \\
\hline Varies/types of food & 2.97 & Medium & - & - \\
\hline Home cooking & 3.03 & Medium & - & - \\
\hline Seafood processing/preserving & - & - & 3.12 & Medium \\
\hline \multicolumn{5}{|l|}{ 7. Language } \\
\hline English speaking in family & 2.53 & Low & & \\
\hline \multicolumn{5}{|l|}{ 8. Sanitation and health } \\
\hline Garbage and waste management on the island & - & - & 3.97 & High \\
\hline Public and underground fresh water supply & - & - & 3.81 & High \\
\hline Sanitary condition of the Urak Lawoi & - & - & 3.46 & High \\
\hline Medication & 2.88 & Medium & - & - \\
\hline \multicolumn{5}{|l|}{ 9. Culture-traditions-beliefs } \\
\hline Traditional culture and ceremonies & - & - & 3.20 & Medium \\
\hline Social values, traditional beliefs and lifestyles & - & - & 3.15 & Medium \\
\hline Obedience and respect to the elders & - & - & 3.13 & Medium \\
\hline Social classes and inferiority of the Urak Lawoi & - & - & 3.11 & Medium \\
\hline Moral and honesty & - & & 3.34 & Medium \\
\hline
\end{tabular}

Levels of impacts as shown in Table 3 were measurement in terms of scores, 5 is the highest and 1 is lowest. The results are concluded as follow;

- The most noticeable positive perception on transitions and changes on the Urak Lawoi's livelihood are household conditions, opportunities for tourism-related occupation, clothing and food consumption behaviors.

- The most worrying negative feeling with regards to transitions and changes within the community are drug addiction among youths, relationships within their own community and officials, lower trust among themselves, most aspects of sanitation and health, all aspects concerning disappearing culture-tradition-beliefs, and lost access to traditionally public areas and sea grounds.

- Other positive perceptions on the transitions and changes are improving self-confidence, better medication, and relationship with foreigner and mainland Thais.

- Other important negative impacts of the transitions and changes facing the Urak Lawoi are increased gambling habits, vanishing indigenous knowledge on fish/seafood processing, decreasing fish harvest and limited recreation areas.

In summary, it can be seen that livelihood changes of the Urak Lawoi has been more positive than negative in terms of their household standards, clothing, and consumption pattern. On the other hand their internal social relationships, their hygienic and sanitary standard as well as erosion of their traditional culture have to be seen 
as highly negative to the Urak Lawoi and social identity. However, improved occupation opportunity and daily life are perceived to be both positive and negative to the Urak Lawoi and the perceptions need to be balanced to assess the long-term implications.

According to each score of sub-indicators, it is clearly seen that waste and lack of solid waste management, relationships with the park officials and drug addiction of youths were among the aspects that was reported to have the highest negative impact. Among the positive changes indicated by the respondents were convenience to travel to and from the mainland, higher income, and alternative tourism related occupation.

\section{Discussion}

The Urak Lawoi are the first recorded inhabitants of Lipe Island. Traditionally, their houses stood on submerged beaches where they could look out to the sea and watch over their boats. For them, the sea and near shore areas are not only their main sources of livelihoods, but also their homes. This study noted that rapid tourism development, with large-scale hotels and bungalow resorts, has significantly affected the livelihoods of the Urak Lawoi in both positive and negative ways. They have been forced farther inland and the communities are clustered in unproductive areas or to other remote areas on the island.

The negative impact aspects that this study emphasizes are loss trust among Urak Lawoi community members, loss of access to traditional public land, beaches and fishing grounds, lack of fish landing facilities (i.e., dock, and pier). The government organizations that have the mandate to address these issues should demarcate specific area/land (with access to beaches and the sea) for the Urak Lawoi that are sufficiently large to preserve their ethnic and cultural identity. They should support the development of fishery and other products to help the Urak Lawoi community at Lipe Island to develop their own initiatives and skills.

\section{Acknowledgments}

This research was financed by the Gradate School, Prince of Songkla University (PSU) and the Southeast Asian Fisheries Department Center (SEAFDEC).

\section{References}

Ashley, C. (2000). The impact of tourism on rural livelihoods: Namibia's Experience. Working paper 128. Overseas Development Institute: UK.

Ashley, C., Boyd, C., \& Goodwin, H. (2000). Pro-poor tourism: Putting poverty at the heart of the tourism agenda. Overseas Development Institute: UK.

Bah, A., \& Goodwin, H. (2005). Pro-poor tourism benefit for local and more fun for tourist. Society and Economy. Natural Resources Institute: UK.

Croes, R. H. (2007). The impact of Tourism on the economy and population of small islands: the case of Aruba. Retrieved June 8, 2013, from http://igitur-archive.library.uu.nl/dissertations/2007-1011-201118/full.pdf

Granbom, A. (2005). Urak Lawoi. Working Paper in Social Anthropology. Department of Sociology. Lund University: Sweden.

Henry, M. A. L. (2012). Impact of tourism on livelihood of communities adjoining ecodestinations in Plateau state. Nigeria. Cultur, 6, 55-70.

Hogan, D. (1972). Men of the sea: coastal tribes of south Thailand's west coast. Journey of the Siam society, 60, 205-235.

King Mongkut's Institute of Technology Ladkrabang. (2010). Integrated tourism management system of Lipe Island, Koh Sarai sub-district, Muang distric, Satun province. Final report. Bangkok.

Teresa, C. (2006). Tourism as a Livelihood Strategy in Indigenous Communities: Case Studies from Taiwan. $\mathrm{Ph} . \mathrm{D}$ Dissertation. University of Waterloo, Canada.

The King's Royally Initiated Laem Phak Bia Environmental Research and Development Project. (2009). The report of environmental quality on Lipe island. Kaseatsart university: Bangkok.

Tourism Thailand Organization. (2013). Marketing database. Retrieved July 16, 2013, from http://marketingdatabase.tat.or.th/ewt_news.php?nid=1621

Wongbusarakum, S. (2002). The Urak Lawoi and the Complexity of Sustainable Resource Use: the Adang Archipelago, Andaman Sea, Thailand. Ph.D Dissertation. University of Hawai, United States of America.

\section{Copyrights}

Copyright for this article is retained by the author(s), with first publication rights granted to the journal.

This is an open-access article distributed under the terms and conditions of the Creative Commons Attribution

license (http://creativecommons.org/licenses/by/3.0/). 